Proceedings

\title{
Use of Multicriteria Analysis Method DEXi to Define Priorities in Implementation of Irrigation Plans ${ }^{\dagger}$
}

\author{
Barbara Karleuša ${ }^{1, *}$, Andreja Hajdinger ${ }^{2}$ and Lidija Tadić ${ }^{2}$ \\ 1 Department of hydrotechnical and geotechnical engineering, Faculty of Civil Engineering University of \\ Rijeka, Rijeka 51000, Croatia \\ 2 Department of hydrotechnical engineering and environmental protection, Faculty of Civil Engineering \\ Josip Juraj Strossmayer University of Osijek, Osijek 31000, Croatia; hajdingerandrej@gmail.com (A.H.); \\ ltadic@gfos.hr (L.T.) \\ * Correspondence: barbara.karleusa@uniri.hr; Tel.: +385-51-265-935 \\ + Presented at the 3rd EWaS International Conference on "Insights on the Water-Energy-Food Nexus", \\ Lefkada Island, Greece, 27-30 June 2018.
}

Published: 3 August 2018

\begin{abstract}
Methodology for determining priorities in implementing irrigation plans using multicriteria analysis method DEXi is applied on the specific case study area in the sub-catchment area of river Orljava in Požega-Slavonia County, Croatia. Five potential irrigation areas are analyzed according to five selected criteria: environmental protection, water-related (4 sub-criteria), social, economic and time criteria with different criteria importance (weight). The aims of this paper are: confirm the adequacy of using DEXi method when determining priorities in fulfilling irrigation plans; present the model for preparation of the input data; apply the method and give feedback on the application.
\end{abstract}

Keywords: multicriteria analysis; DEXi; priority; irrigation plan implementation; Požega-Slavonia County; Croatia

\section{Introduction}

Decision making in water management planning process is very complex. This is caused by multiple objectives that have to be satisfied, different and numerous criteria (economic, social and environmental) and different measures (quantitative and qualitative) used for objective fulfillment assessment, with the involvement of multiple stakeholders [1,2]. Usually, more than one alternative/solution can be developed for solving a specified problem among which the optimal has to be selected. There are numerous procedures, classified as multicriteria analysis (MCA) methods, that give support to this kind of complex decision-making processes [3-5].

Multicriteria decision analysis has been used for analyses of different types of water management problems [6], for ranking and selection of: water management strategies $[7,8]$, alternatives of irrigation [9-11] or water supply systems [12], reservoir use alternatives [13], desalination procedures for drinking water production [14], wastewater disposal locations [15], urban stormwater drainage management alternatives [16], locations for hydropower plants and dams [17] etc.

Multicriteria analyses methods AHP (Analytic Hierarchy Process), PROMETHEE (Preference Ranking Organization METHod for Enrichment Evaluations) and ELECTRE (ELimination and (Et) Choice Translating Reality) TRI have proven, based on authors research, to provide support in decision making for defining priorities in the implementation of agricultural irrigation plans $[11,18]$. 
This paper deals with the application of multicriteria analysis method DEXi on the specific case study in Croatia where priorities in implementation of the Irrigation plan of Požega - Slavonia County are analyzed.

The aims of this paper are: confirm the adequacy of using the DEXi method when determining priorities in fulfilling irrigation plans; present the model for preparation of the input data for DEXi method application; by analyzing the use of DEXi application on the specific case study (PožegaSlavonia County irrigation plan) give feedback about the method application.

\section{Materials and Methods}

\subsection{Case Study}

The case study area is located in Požega-Slavonia County (north-eastern part of Croatia, Figure 1), in the sub-catchment area of river Orljava that belongs to the Sava River Basin [19]. The Orljava River basin consists of valleys, terraces, and hills, mostly covered with forests, meadows and cultivated areas.

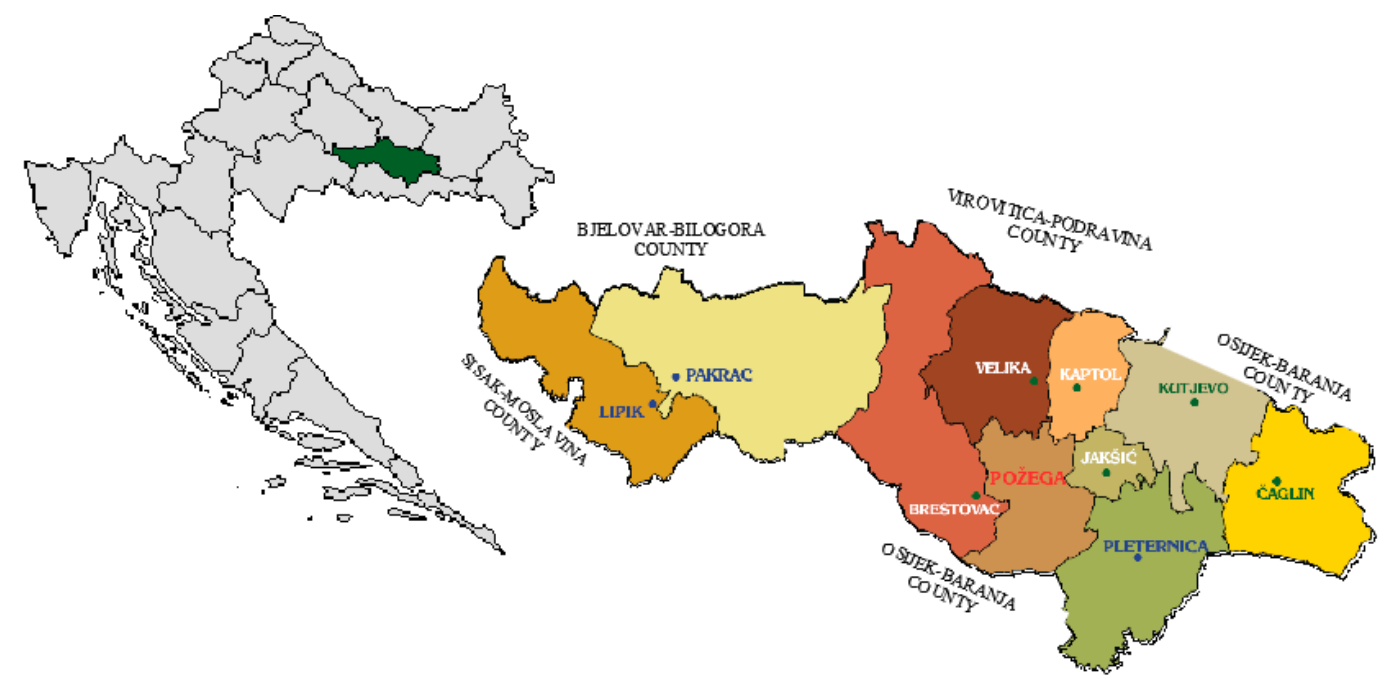

Figure 1. Position and organization of Požega-Slavonia County [19].

According to the Spatial plan of the Požega-Slavonia County, it is stated that agricultural land occupies the largest share in the county, and that wheat, maize, sugar beet, tobacco, grape, fruits, and vegetables are mostly grown [20]. Agricultural land can be divided into three categories: especially valuable soil, valuable soil, and other cultivable soil. Considering the cultivability of agricultural areas, it was found that from the total area of $894.9 \mathrm{~km}^{2}$, the cultivated area covers $782.9 \mathrm{~km}^{2}$ or $87.48 \%$ [19-21].

According to data from year 2003 [22], only 1085.6 ha were irrigated in the Požega-Slavonia County, which is only $2.55 \%$ of its total area suitable for irrigation. This percentage is higher than the average in Croatia, that amounts only $0.86 \%$, but still insufficient to realize its own potential.

To intensify the agricultural production, enable development in the area, raise the standard and the quality of life a significant contribution can be expected if irrigation is applied to agricultural areas. Analyzes carried out in the Požega area show that the total surface where irrigation is needed is 40,772 hectares of gross $(29,327$ ha net).

These analyzes have shown that the need for irrigation exists as a supplementary measure for the improvement of agricultural production. The amount of water from 1500 to $2500 \mathrm{~m}^{3} /$ ha per year can meet the water needs of all crops. Areas that could potentially be irrigated are located in central part of the Orljava River basin.

The entire study area is characterized by small quantities of groundwater and with high potential for building multipurpose reservoirs and micro-reservoirs. Water for irrigation, approximately $77 \mathrm{mil} . \mathrm{m}^{3}$, can be provided by reservoirs of various sizes [20]. 
The planning of irrigation is based on selecting water resources that will provide the needed quantities and can be divided into three phases. The first phase involves the construction of microreservoirs and preparation of pilot irrigation areas. The second phase is the development of small and medium-sized systems based on the first stage knowledge and preparation for the performance of larger systems, where coordination is needed in terms of aligning plans with other relevant factors. The third phase is the performance of medium and large systems [19].

In the first phase five potential irrigation areas (alternatives) that belong to the river Orljava subcatchment area are observed in detail in this paper. The analysis of alternatives is done according to five selected criteria: environmental protection, water-related criteria (consists of four sub-criteria), social, economic and time criteria. Each criterion importance is defined with the weight factor.

The development of agriculture and agricultural production provides significant opportunities for Požega-Slavonia County. A major problem is that agriculture has not been yet developed according to its capabilities. The main reason is the fragmentation of the parcels. It is necessary to improve harmonization on the state, county and lower levels in order to stimulate development and to achieve production results that would meet the needs of Požega-Slavonia County and even for export [19]. The problem of fragmentation of the parcels was not analysed in this paper.

\subsection{Alternatives and Criteria}

Planned irrigation areas in the 1st phase represent only a small part of the area of PožegaSlavonia County which can be irrigated. The areas defined are the result of activities of the County administration and Croatian Waters in an attempt to find potential irrigation users. If the irrigation projects start in these areas, the needs and priorities in the development of agricultural production in the County could be identified [19]. This is the reason why it is important to select the first pilot area to implement the irrigation.

Planned irrigation areas (alternatives) in the 1st phase are Orljava and Londža, Pleternica, Ovčare, Treštanovci, and Venje-Hrnjevac (Figure 2).

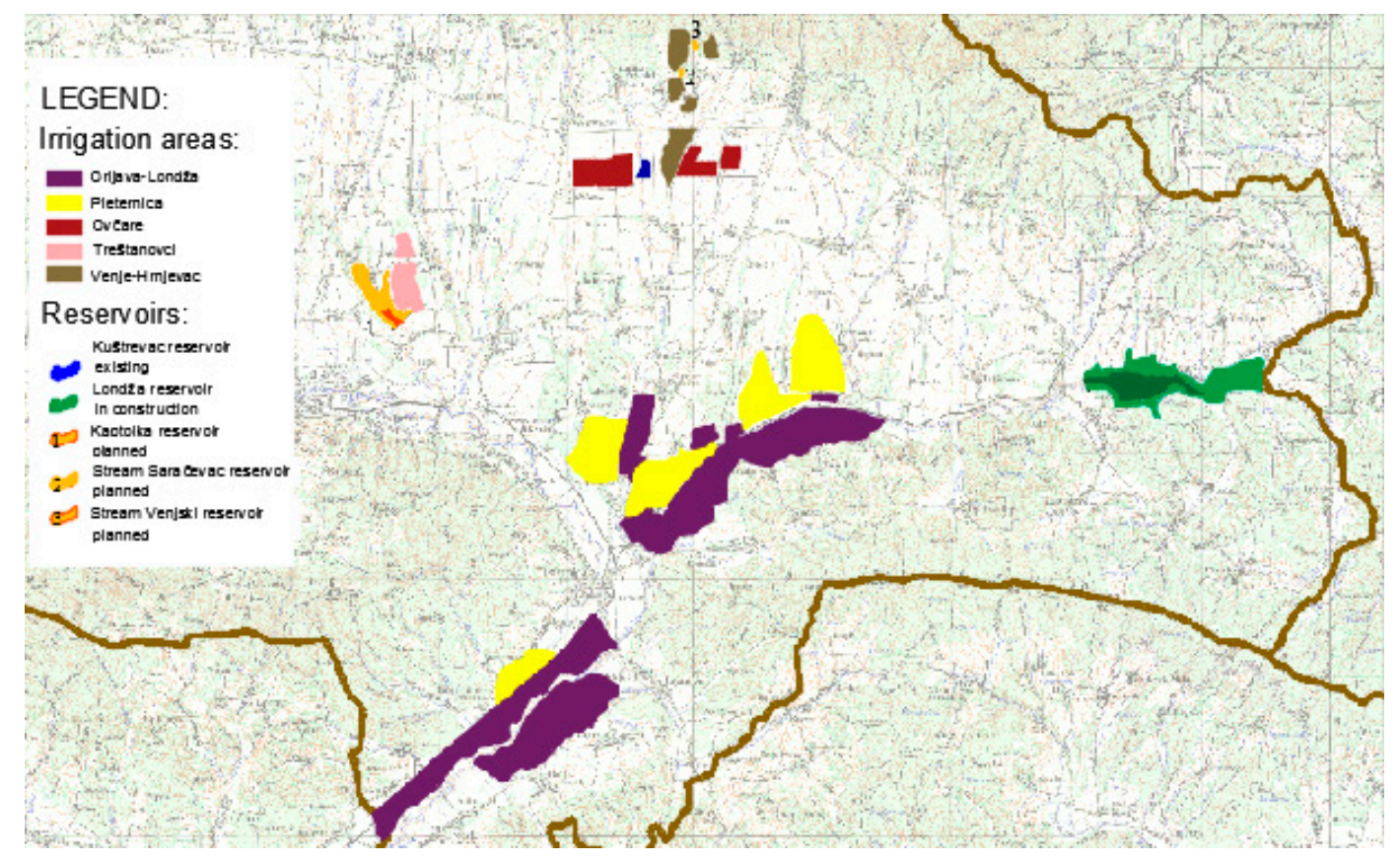

Figure 2. Planned irrigation areas and location of reservoirs.

Based on analyses done in the study "Basics for irrigation in Požega-Slavonia County" [19] the most important characteristics of all areas (alternatives) are presented in Table 1. Based on these available characteristics five group criteria were defined: "environmental protection", "waterrelated", "social", "economic" and "time" criteria (Table 2). 
Table 1. Characteristics of all areas (alternatives) [19].

\begin{tabular}{|c|c|c|c|c|c|c|c|c|c|c|c|c|c|c|c|}
\hline \multirow[t]{2}{*}{ Alternative } & \multirow[t]{2}{*}{ Investor/User } & \multirow{2}{*}{$\begin{array}{c}\text { Protection } \\
\text { Area }\end{array}$} & \multirow{2}{*}{$\begin{array}{c}\text { Ownership } \\
\text { Type }\end{array}$} & \multicolumn{2}{|c|}{$\begin{array}{c}\text { State of Drainage } \\
\text { and Channel } \\
\text { Network }\end{array}$} & \multicolumn{3}{|c|}{ Agricultural Production } & \multirow[t]{2}{*}{ Reservoir } & \multirow{2}{*}{$\begin{array}{c}\text { Possibility } \\
\text { to Use } \\
\text { Reservoir } \\
\text { for } \\
\text { Recreation }\end{array}$} & \multirow{2}{*}{$\begin{array}{c}\text { Water } \\
\text { Demand } \\
\text { (Mil. } \\
\text { m }^{3} / \text { Year) }\end{array}$} & \multirow{2}{*}{$\begin{array}{c}\text { Time to } \\
\text { Complete } \\
\text { the } \\
\text { System } \\
\text { (Years) } \\
\end{array}$} & \multirow{2}{*}{$\begin{array}{l}\text { Cost of Project } \\
\text { Documentation } \\
\text { Preparation } \\
\text { (Mil. Kn) }\end{array}$} & \multirow[t]{2}{*}{$\begin{array}{c}\text { Investment } \\
\text { (Mil. Kn) }\end{array}$} & \multirow{2}{*}{$\begin{array}{c}\text { Total Cost Per } \\
\text { Agricultural Area } \\
\text { (Kn/ha) }\end{array}$} \\
\hline & & & & Drainage & Cannels & Existing & Planned & Area (ha) & & & & & & & \\
\hline ORLJAVA-LONDŽA & Kutjevo Ltd. & DWPZ & Rent & Partially & Exists & $\begin{array}{l}\text { Soy, lucerne } \\
\text { and maize }\end{array}$ & $\begin{array}{l}\text { Maize, } \\
\text { sugar beet, } \\
\text { soy, } \\
\text { rapeseed }\end{array}$ & 2500 & $\begin{array}{l}\text { Lodža-in } \\
\text { construction }\end{array}$ & Yes & 6.250 & 3 to 5 & 1.5 & 37.5 & 15,600 \\
\hline PLETERNICA & Hrvatski duhani Ltd. & DWPZ & Management & None & Partially & Tobacco & Tobacco & 300 & $\begin{array}{c}\text { Lodža-in } \\
\text { construction }\end{array}$ & Yes & 0.75 & 3 to 5 & 0.35 & 9 & 31,167 \\
\hline OVČARA & Kutjevo Ltd. & No & Rent & Partially & Exists & $\begin{array}{l}\text { Vine grafts, } \\
\text { maize and } \\
\text { sugar beet }\end{array}$ & $\begin{array}{c}\text { Vine } \\
\text { grafts, } \\
\text { maize and } \\
\text { sugar beet, } \\
\text { industrial } \\
\text { and seed } \\
\text { crops }\end{array}$ & 200 & $\begin{array}{l}\text { Kuštrevac- } \\
\text { existing }\end{array}$ & No & 0.5 & 1 to 2 & 0.28 & 7 & 36,400 \\
\hline TREŠTANOVCI & Grbić Ltd. & No & Private, rent & None & None & Seed crops & $\begin{array}{c}\text { Seed } \\
\text { production }\end{array}$ & 150 & $\begin{array}{l}\text { Kaptolka, } \\
\text { Kljunovac- } \\
\text { planned }\end{array}$ & No & 0.375 & 3 & 0.15 & 3.75 & 26,000 \\
\hline VENJE-HRNJEVAC & Winery Enjingi & Nature Park & Private, rent & None & None & $\begin{array}{l}\text { Vineyards } \\
\text { and vine } \\
\text { grafts }\end{array}$ & Vineyards & 80 & $\begin{array}{l}\text { Saračevac } \\
\text { and Venjski- } \\
\text { planned }\end{array}$ & Yes & 0.2 & 3 & 0.2 & 5.1 & 66,250 \\
\hline
\end{tabular}


Table 2. Characteristics of all areas sorted by selected criteria [19].

\begin{tabular}{|c|c|c|c|c|c|c|c|c|}
\hline \multirow[b]{2}{*}{ Criteria Alternatives } & \multirow[b]{2}{*}{$\begin{array}{l}\text { Environ. } \\
\text { Protection } \\
\text { Type }\end{array}$} & \multicolumn{4}{|c|}{ Water Related } & \multirow{2}{*}{$\begin{array}{c}\text { Social } \\
\text { Recreation }\end{array}$} & \multirow{2}{*}{$\begin{array}{c}\text { Economic } \\
\text { Total Cost } \\
\text { per } \\
\text { Agricultural } \\
\text { Area (Kn/ha) }\end{array}$} & \multirow[b]{2}{*}{$\begin{array}{c}\text { Time } \\
\text { Time to } \\
\text { Complete } \\
\text { the System } \\
\text { (Years) }\end{array}$} \\
\hline & & Drainage & Channels & $\begin{array}{c}\text { Area to } \\
\text { be } \\
\text { Irrigated } \\
\text { (ha) }\end{array}$ & $\begin{array}{c}\text { Status of } \\
\text { Reservoir } \\
\text { Construction }\end{array}$ & & & \\
\hline PLETERNICA & DWPZ & None & Partially & 300 & in construction & Yes & 31,167 & 3 to 5 \\
\hline OVČARE & No & Partially & Exists & 200 & existing & No & 36,400 & 1 to 2 \\
\hline TREŠTANOVCI & No & None & None & 150 & planned & No & 26,000 & 3 \\
\hline
\end{tabular}

The "environmental protection" criterion evaluates whether the agricultural area is in the drinking water protection zone-DWPZ (worst), other protected area e.g., nature park, national park, or does not belong to any of the specified (best). The weight factor for the "environmental protection" criterion is $20 \%$.

The "water-related" criterion comprises of four sub-criteria. The first of is "drainage". It evaluates whether the drainage form agricultural areas is partially built (best), or not existing/none (worst). The weight factor for sub-criterion "drainage" (subsurface drainage) is 5\%. The second subcriterion is "channel" (surface drainage), and is evaluated depending on whether the channel networks are completely built/exist (best), partially, or do not exist at all/none (worst). The weight factor for "channel" network sub-criterion is $5 \%$. The third sub-criterion is related to the size of the "area to be irrigated". Larger the area, better the alternative, divided in classes 0-149 (worst), 150449 and over 450 ha (best). The weight factor for sub-criteria of the irrigated area is $10 \%$. The fourth sub-criterion is related to "status of reservoir construction" ranking from already existing reservoir that could be used for irrigation (best), reservoir which construction has already started and reservoir which construction is only planned (worse). The total weight factor for this last sub-criterion accumulation is $10 \%$. The total weight factor for "water-related" criterion is $30 \%$.

The "social" criterion is related to the possibility of using reservoirs for recreation, reservoirs that can be used for recreation (best) or not (worse). The weight factor for the "social" criteria is $5 \%$.

The "economic" criterion covers the total cost of the irrigation systems (the cost of designing the project and all needed documentation and the cost of building the whole system in Croatian currency Kuna-kn) divided by the size of the irrigated area, sorting alternatives in three classes: 0 to 24,999.99 (best); $25,000.00$ to 55,000.00, and over 55,000.00 kn/ha (worst). The weight for the "economic" criterion is $30 \%$.

The "time" criterion describes the time needed to build a system, which can be 1-2 years (best), $2-3$ years and 3-5 years (worst). The weight factor for the "time" criterion is $15 \%$.

The weight factors were determined by authors, considering beside the technical part (waterrelated criteria), also the importance of the environmental protection and its value, economic development and value of money.

\subsection{DEXi Method}

When making strategic and operational decisions, it is often difficult to quantitatively express all elements of the observed problem due to the unavailability or lack of information or the complexity of the problem itself. In order to have timely decision making, it is possible to replace the quantitative methods of decision making with qualitative ones.

DEXi (Decision Expert) decision model is a qualitative decision model. It was developed at the beginning of the 1980s at the "Jožef Stefan" Institute in Ljubljana (Slovenia), and is still in us today [23]. DEXi models have proven to be very successful in situations where complex decision models are needed, there is a large number of criteria and/or alternatives, and/or the data are unreliable and/or do not exist.

The basic approach in DEXi methodology is the multi-objective analysis of the problem by which the decision-making problem is divided into less complex decision-making problems (sub-problems). Criteria are hierarchically organized and linked to the utility function. Utility function evaluates each criterion in relation to its goal in the hierarchy. Instead of numeric variables, DEXi uses qualitative 
variables, whose values are usually presented in words. To display and evaluate the utility function, DEXi uses "if-then" decision-making rules. The utility function is defined throughout the hierarchy for each set of criteria, and the decision rule is described (Figure 3). The value of the aggregate criterion for each combination of input criteria is described and the relative importance of each criterion is expressed.

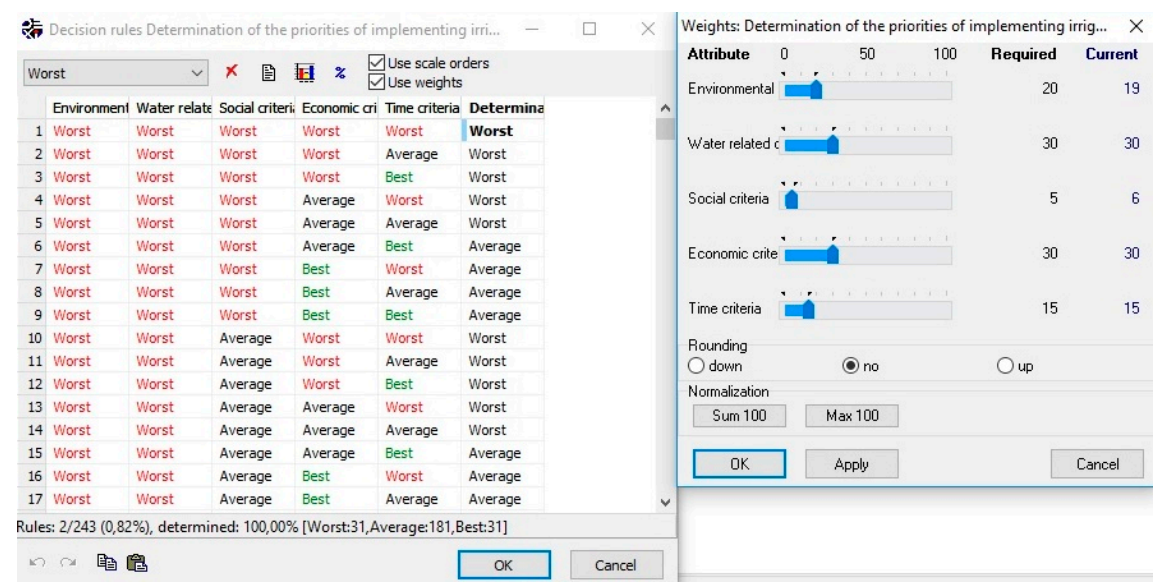

Figure 3. Defining the utility function.

If the utility function is to be displayed in less detail, the weight factor is used. By expressing the importance of the input element in percentage versus the other variables the desired weight is obtained. Two methods are used to estimate weight factors in DEXi, one based on regression, and the other on the informative measurement of criteria. If the regression method is used, the decision is interpreted as a set of points in a multidimensional space, all qualitative values are represented by ordinal numbers, so a decision rule can be interpreted as a collection of points. An alternative method for estimating weight factors is the method used in identifying algorithms of the most relevant methods. The method is based on the theoretical measure of entropy $\mathrm{H}(\mathrm{X})$ :

$$
H(X)=-\sum P\left(x_{i}\right) \log _{2} P\left(x_{i}\right)
$$

where $\mathrm{P}$ is the probability of $\mathrm{x}_{\mathrm{i} \text {-events. }}$

Another way of defining the utility function is the so-called "weight-based" definition of a decision, which refers to defining only a small set of rules but further defines the required weighting criteria. The higher the weight, the more important the criterion. Using the above information DEXi constructs a linear function by which software interpolates the values. The function is constructed so that its linear coefficients are as close as possible to the initial subset. At the very beginning of the work in DEXi software, it is necessary to define the name of the evaluation and define the criteria (with sub-criteria if available). Within each criterion, the ranking is performed depending on whether its value is good, neutral, or poor. Ranking needs to be made for each criterion, with the order in which the values of the criteria are entered. After defining the criteria and their value, the utility function is defined, applying the "if-then" decision rule. The utility function is defined for each criterion. The next step is to define the alternatives. For each alternative, a certain value is assigned from the drop-down menu, after which the evaluation is done, that is the software processes the entered data and displays the results of the analysis [6].

\section{Results}

DEXi software allows the display of results in multiple graphical modes. The first way is to display the final evaluation in which all the results of the analysis are combined (Figure 4a), the alternatives that are recommended, partially recommended or not recommended are displayed. The results can also be presented according to a certain criterion, which also specifies the areas that are recommended, partially recommended or not recommended according to that criterion. The results 
can be presented also for two criteria. In this case, the results are no longer presented in line but are projected at the point at the intersection for both criteria (Figure $4 \mathrm{~b}$ ).

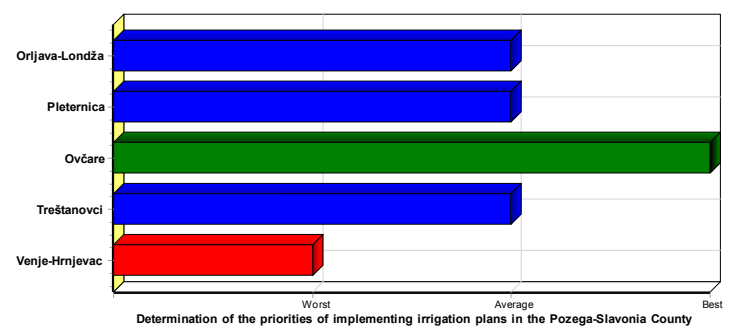

(a)

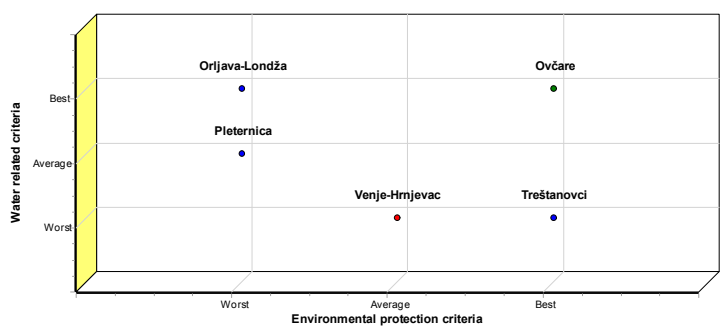

(b)

Figure 4. (a) Final result; (b) Results for two criteria.

The presentation of results for three or more criteria is done on a polygon. An ideal alternative would represent an unbroken line that moves at the top of the polygon. If the results vary between good and medium, the line is in the space between the center and the top of the polygon, while for the worse results there is no line, i.e., there is no shift from the point that indicates the center of the polygon.

The results for each alternative according to the defined criteria are shown on Figures 5-9.
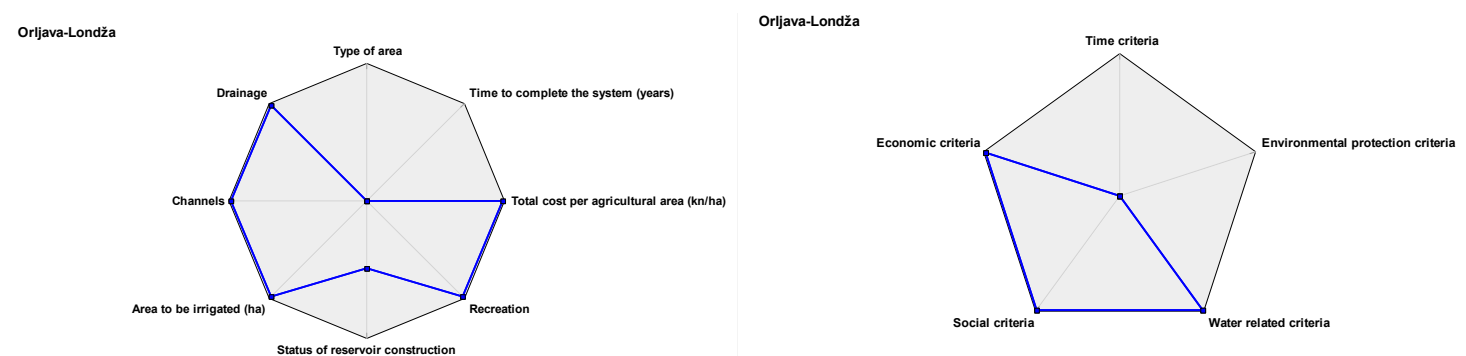

Figure 5. Result of Orljava-Londža alternative analyses.

Pleternica
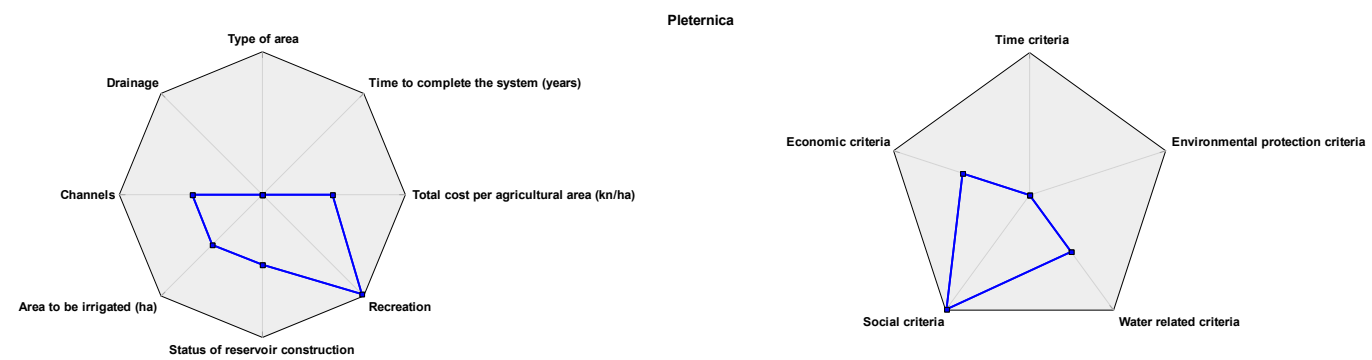

Figure 6. Result of Pleternica alternative analyses.

Ovčare

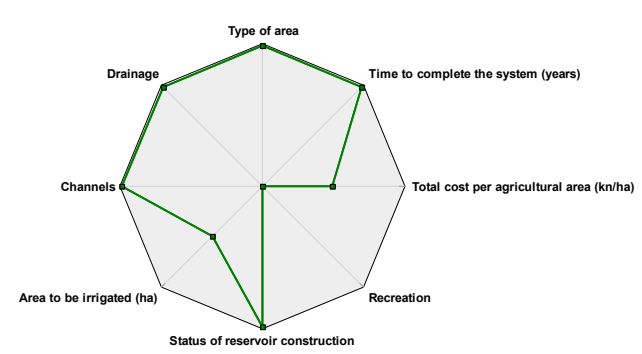

Ovčare

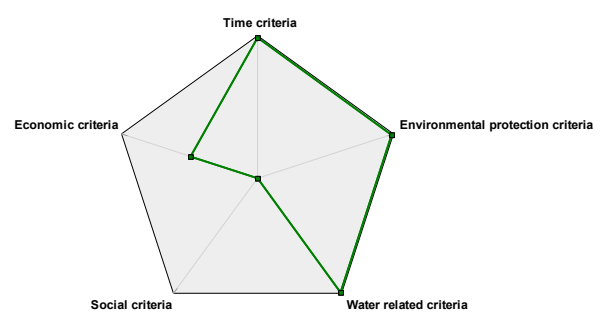

Figure 7. Result of Ovčare alternative analyses. 

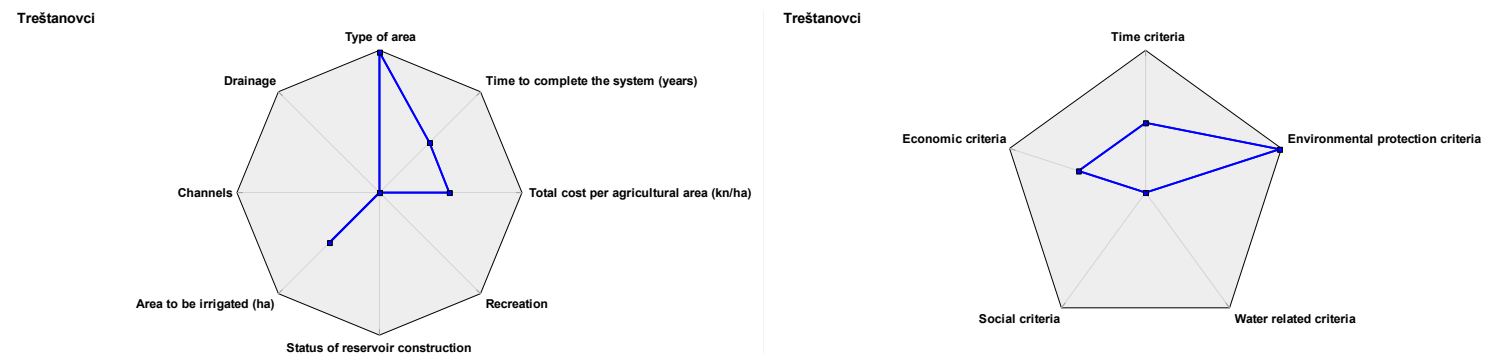

Figure 8. Result of Treštanovci alternative analyses.
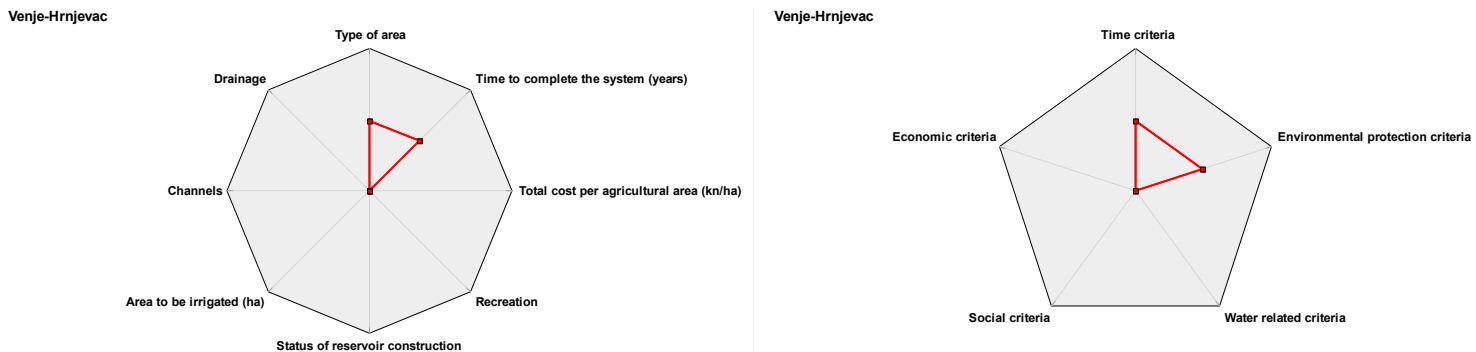

Figure 9. Result of Venje-Hrnjevac alternative analyses.

According to the conducted analysis using the DEXi software the area of Ovčare is recommended as the first in which the irrigation should be implemented (Figure 7). The areas of Orljava and Londža; Pleternica, and Treštanovci (Figures 5, 6 and 8) are partially recommended, while the area of Venje-Hrnjevac (Figure 9) is not recommended.

\section{Discussion}

Ovčare is estimated as the recommended area. The reservoir for irrigation already exists, and the time to complete the irrigation system is up to 2 years, the agricultural area is not in any restricted (protected) zone, the status of the drainage system is mostly built, and the cost is not the highest, although the reservoir is not used for recreation. The final results depend on criteria involved in the analysis and their weighting factors. Their definition is the most sensitive part in the multi-criteria evaluation. They should present realistic and objective characteristics of the study field in order to result with an objective and valuable decision. It should be emphasized that the idea of the irrigation system in this area is only in the beginning and that by the realization, of the projects, building the drainage, the channel network will change in better. For the other four irrigation areas/alternatives, the situation will be significantly changed by the construction or completion of reservoirs, which will encourage other users to develop the irrigation system.

\section{Conclusions}

In the case study area of Požega-Slavonia County, five potential irrigation areas (alternatives) were analyzed according to the defined criteria using multicriteria analysis method and software DEXi. The area of Ovčare was chosen as the most appropriate alternative to start with the implementation of the irrigation development plan. It can be concluded that the final results depend on criteria involved in the analysis and their weighting factors. Since the weighting factors in this research were defined by authors considering beside the technical part (water-related criteria), also the importance of environmental protection and its value, economic development and value of money, further research should involve stakeholders in the definition of weight factors. The area of Ovčare can be further tested. Since it consists of a number of plots, with the total area of 200 ha, the proposed software DEXi can be a helpful tool for evaluating those plots for irrigation.

Working in DEXi software is based on a qualitative description of the alternatives and criteria. The software has shown to be very well designed and easy to use. The results are presented through interesting diagrams according to user's choice (one criterion, combination of criteria, all criteria), in 
order to make decision making easier for decision makers. The graphical presentations can be also used to analyze the sensitivity of the results in relation to the change in weight factors (importance) for criteria.

It can be concluded that the adequacy of using DEXi method when determining priorities in fulfilling irrigation plans can be confirmed. The analyzed method gives the opportunity for development of the complex structure of various criteria and their weighting factors in an easy way and short time period. The use of qualitative measures must be emphasized as an important advantage of DEXi method in cases where it is difficult to give quantitative evaluations of alternatives. Further research should include a more detailed comparison with other MCA methods.

Acknowledgments: This research was conducted within the University of Rijeka funded project: “Development of New Methodologies in Water and Soil Management in Karstic, Sensitive and Protected Areas" (13.05.1.3.08).

\section{References}

1. Đorđević, B. Vodoprivredni Sistemi; Naučna knjiga: Beograd, Serbia, 1990; ISBN 86-23-41056-4.

2. Margeta, J. Osnove Gospodarenja Vodama; Građevinski Fakultet: Split, Croatia, 1992.

3. Opricović, S. Višekriterijumska Optimizacija; Naučna Knjiga: Beograd, Serbia, 1986.

4. Triantaphyllou, E. Multi-Criteria Decision Making Methods: A Comparative Study; Kluwer Academic Publishers: Dordrecht, The Netherlands, 2000; ISBN 978-1-4939-3094-4.

5. Figueira, J.; Greco, S.; Ehrogott, M. Multiple Criteria Decision Analysis: State of the Art Surveys. In International Series in Operations Research E Management Science; Springer: New York, NY, USA, 2005; Volume 78, ISBN 978-0-387-23081-8.

6. Hajkowicz, S.; Collins, K. A review of multiple criteria analysis for water resource planning and management. Water Resour. Manag. 2007, 21, 1553-1566, doi:10.1007/s11269-006-9112.

7. Raju, K.S.; Pillai, C.R.S. Multi-criterion decision making in river basin planning and development. Eur. J. Oper. Res. 1999, 112, 249-257, doi:10.1016/S0377-2217(98)00006-X.

8. Duckstein, L.; Treichel, W.; El Magnouni, S. Ranking Ground-water Management Alternatives by Multicriterion Analysis. J. Water Resour. Plann. Manag. 1994, 120, 546-565, doi:10.1061/(ASCE)07339496(1994)120:4(546).

9. Raju, K.S.; Pillai, C.R.S. Multicriterion decision making in performance evaluation of an irrigation system. Eur. J. Oper. Res. 1999, 112, 479-488, doi:10.1016/S0377-2217(98)00007-1.

10. Goncalves, J.M.; Pereira, L.S.; Fang, S.X.; Dong, B. Modelling and multicriteria analysis of water saving scenarios for an irrigation district in the upper Yellow River Basin. Agric. Water Manag. 2007, 94, 93-108, doi:10.1016/j.agwat.2007.08.011.

11. Karleuša, B.; Ožanić, N. Određivanje prioriteta u realizaciji vodnogospodarskih planova/Determination of priorities during realization of water management plans. Građevinar 2011, 63, 151-161, Available online: http://www.casopis-gradjevinar.hr/archive/article/371 (accessed on 1 November 2018).

12. Paneque Salgado, P.; Corral Quintana, S.; Guimardes Pereira, A.; del Moral Ituarte, L.; Pedregal Mateos, B. Participative multi-criteria analyseis for the evaluation of water governance alternatives. A case study in the Costa del Sol (Malaga). Ecol. Econ. 2009, 68, 990-1005.

13. Srđević, B.; Jandrić, Z.; Potkonjak, S. Vrednovanje alternativa korištenja akumulacije pomoću analitičkog hijerarhijskog procesa/Assessment of alternatives for reservoir use with analytic hierarchy process. Jugosl. Čas. Vodoprivr. 2000, 32, 237-242.

14. Afify, A. Prioritizing desalination strategies using multi-criteria decision analysis. Desalination 2010, 250, 928-935, doi:10.1016/j.desal.2009.03.005.

15. Margeta, J. Izbor optimalnog rješenja dispozicije otpadnih voda Poljičke rivijere/Selection of the optimal solution for waste water disposal of Poljička riviera. Vodoprivreda 1986, 18, 79-87.

16. Martin, C.; Ruperd, Y.; Legret, M. Urban stormwater drainage management: The development of a multicriteria decision aid approach for best management practices. Eur. J. Oper. Res. 2007, 181, 338-349, doi:10.1016/j.ejor.2006.06.019.

17. Margeta, J.; Mladineo, N.; Petričec, M. Višekriterijsko rangiranje lokacija za male hidroelektrane/Multicriteria ranking of locations for small hydropower plants. Građevinar 1987, 39, 239244. 
18. Karleuša, B.; Ožanić, N.; Deluka-Tibljaš, A. Improving decision making in defining priorities for implementation of irrigation plans using AHP methodology. Tech. Gazette 2014, 21, 673-680; Available online: https://hrcak.srce.hr/index.php?show=clanak\&id_clanak_jezik=182226 (accessed on 1 November 2018).

19. Hidroprojek-ing, D.O.O.; Hidroing, D.O.O. Osnove Navodnjavanja na Području Požeško-Slavonske Županije/Basics for Irrigation in Požega-Slavonia County; Zagreb/Osijek, Croatia, 2005.

20. Prostorni Plan Požeško-Slavonske Županije/Spatial Plan of Požega-Slavonia County. In Požeško-Slavonski Službeni Glasnik; Požega, Croatia, 2015.

21. Razvojna Strategija Požeško-Slavonske Županije za Razdoblje 2011-2013; Develpoment Strategy of PožegaSlavonia County: Požega, Croatia, 2011.

22. Kantoci, D. Navodnjavanje/Irrigation. Glasnik Zaštite Bilja 2012, 35, 66-72; Available online: https://hrcak.srce.hr/index.php?show=clanak\&id_clanak_jezik=240422 (accessed on 5 October 2018).

23. Rozman, Č.; Pažek, K. Introduction to DEXi multi criteria decision models: What they are and how to use them in agriculture. Agricultura 2012, 9, 23-30; Available online: http://www. agriculturaonline.com/portal/issues/50-issue-16/153-introduction-to-dexi-multi-criteria-decision-models-what-theyare-and-how-to-use-them-in-agriculture (accessed on 23 November 2017).

(C) 2018 by the authors. Licensee MDPI, Basel, Switzerland. This article is an open access article distributed under the terms and conditions of the Creative Commons Attribution (CC BY) license (http://CREATIVECOMMONS.org/licenses/by/4.0/). 